This is an Accepted Manuscript of an article published by Taylor \& Francis in The Journal of Peasant Studies on 2014-01-15, available online:

http://www.tandfonline.com/doi/abs/10.1080/03066150.2013.875536

Full reference: Clapp, Jennifer. "Financialization, Distance and Global Food Politics”, The Journal of Peasant Studies, Vol.41, No. 5, pp. 797-814.

\title{
Financialization, Distance and Global Food Politics
}

\section{Jennifer Clapp}

\begin{abstract}
:
This paper provides a new perspective on the political implications of intensified financialization in the global food system. There has been a growing recognition of the role of finance in the global food system, in particular the way in which financial markets have become a mode of accumulation for large transnational agribusiness players within the current food regime. This paper highlights a further political implication of agrifood system financialization, namely how it fosters 'distancing' in the food system and how that distance shapes the broader context of global food politics. Specifically, the paper advances two interrelated arguments. First, a new kind of distancing has emerged within the global food system as a result of financialization that has a) increased the number of the number and type of actors involved in global agrifood commodity chains and b) abstracted food from its physical form into highly complex agricultural commodity derivatives. Second, this distancing has obscured the links between financial actors and food system outcomes in ways that make the political context for opposition to financialization especially challenging.
\end{abstract}

Keywords: financialization, distance, commodity speculation, land grabs, hunger, civil society 


\section{Introduction}

Recent decades have seen phenomenal growth in the sale and purchase of financial products linked to agricultural commodities and farmland by banks, agricultural commodity trading firms, and investment funds. This trend is taking place alongside a larger process of financialization within the global economy, which has seen financial markets play an increasingly important role in investment decisions and outcomes in a variety of sectors. The food studies literature is only just beginning to examine what this greater role for financial actors in the global economy means for political dynamics within the contemporary global food system (e.g. Burch and Lawrence 2009; Daniel 2012). A growing number of studies have situated financialization within the context of food regimes, showing how new financial instruments are widely used by transnational agrifood corporations as yet another mode of accumulation that further solidifies their dominant role in the global food regime (Burch and Lawrence 2009; McMichael 2012, 2013). This work has been important in developing a deeper understanding of how changing dynamics of capitalism in the global economic context drive corporate investment decisions with repercussions throughout the food system.

This paper highlights an additional political implication of the increased role of financial actors in the food system. At the same time that financialization opens new opportunities for corporate accumulation in the global food system, some of its specific dynamics shape the political context for resistance. In particular, both the increased activity of financial actors and the growing range of specific agriculture-based financial investment tools that they utilize have contributed to a new kind of 'distancing' within the food system. Distance-which includes the geographical expanse from farm to plate along global commodity chains, as well as knowledge gaps about the social and environmental impacts of food production-affects the distribution of power and influence over the governance of the food system (Kneen 1995; Princen 2002; Clapp 2012). Heightened financialization in the global food system contributes to distancing in two ways. First, it increases the number of actors involved in global agrifood commodity chains; and second, it abstracts food from its physical form into highly complex agricultural commodity derivatives that are difficult to understand for all but seasoned financial traders.

Both of these kinds of distancing tend to obscure the role that financial actors play in the food system, making it difficult to link them to the social and ecological consequences of financial investment activities on the ground. Financial derivatives, such as index funds that derive their value from changes in an index tracking the prices of commodities, farmland and agrifood firm shares, have been prominent forms of financial investment in the sector, and have been popular with financial speculators. These financial investments, in turn, affect food prices and provide the capital for firms to make investments in the productive sector, often resulting in negative side effects, including higher and more volatile food prices as well as a host of environmental and 
social problems associated with large-scale farmland acquisitions. But distancing associated with financialization means that the role that financial actors play in fuelling those problems is not always transparent. This lack of transparency about which actors are involved in driving these trends creates space for competing narratives — often advanced by the financial actors themselves - that point to other explanations for negative social and environmental outcomes. Distance thus shapes the political context for groups that seek to oppose financialization in the food system, complicating attempts by civil society to challenge the dominant norms around the role of finance in the food system.

The first section of this paper maps out the theoretical literatures on the rise of financialization, its interpretation thus far in the food studies literature, and the ways in which the concept of distancing can help to further highlight the implications of financialization for food system politics. The subsequent section then illustrates how new kinds of distancing have emerged with the financialization of the food system by tracing the various new actors involved and the types of financial investments they employ that have abstracted food from its physical form and add new decision points within commodity chains. The final section shows that distancing brought about by financialization in the food system has worked to obscure the role of financial actors, and the costs imposed by their activities, in ways that complicate the efforts of civil society groups that seek to reduce the impact of financial actors on food price volatility and hunger.

\section{Finance, Food and Distance}

The growing significance of financial actors in the world economy in recent decades has given rise to a burgeoning literature on 'financialization' and its implications (Epstein 2005; Montgomerie 2008; Engelen 2008). Financialization, as defined by Epstein, refers to the “(I)ncreasing importance of financial markets, financial motives, financial institutions, and financial elites in the operation of the economy and its governing institutions, both at the national and international levels” (Epstein 2005, 3). The literature on financialization has sought to explain how and why financial markets and the associated actors, institutions and structures have emerged as such a powerful force in the global economy as well as their implications. These works have pointed to various political factors - from states' embrace of neoliberal economic ideology to competitive pressures and lobbying of specific private interests - that have driven a dramatic deregulation and globalization of the world's financial markets. Financialization is widely seen to be a response to the exhaustion of the Fordist economic growth model, where financial capital has replaced productive capital in the quest for new profits. This process has seen the rise to dominance of a finance-led form of capitalism in which the ownership of financial assets drives investment decisions and allows for new modes of accumulation (see Montgomerie 2008). The financialization literature has also examined the rise of new relationships between financial markets, firms, individuals and the broader economy (Hall 2012; French et al. 2011). 
Financial actors have had a long role within the food system via futures markets, but this role has grown remarkably in recent decades. Prior to the 2007-8 food crisis, few scholars of financialization had focused their attention specifically on the food sector (Clapp and Helleiner 2012a). But rapidly rising and volatile food prices in that crisis encouraged a number of scholars to begin to note the growing role of financial speculation on agricultural commodity futures markets as one of the contributing causes of those price trends (Clapp 2009; Mittal 2009; Ghosh 2010). Looking at the structural causes and consequences of the rise of financial actors in the food system, several scholars have sought to explain the rise of financialization in the food sector as part of the broader trend toward a finance-led capitalism within the corporate food regime (Burch and Lawrence 2009; McMichael 2012). Mirroring the broader financialization literature, these works make the case that financialization provides an additional accumulation strategy for major agrifood firms within a transformed global food regime. This work shows that profitseeking financial actors in turn channel speculative investments into the sector, enabling transnational corporations, including large agribusiness and supermarket chains, further opportunity for profit accumulation (Burch and Lawrence 2009; McMichael 2005; 2009; 2013). Some have also pointed to the role of financial speculation in land grabs, as financial capital is drawn to the fixed asset of land and the revenues that flow from the offshoring of agriculture, which also serves corporate accumulation strategies (Daniel 2012; Cotula 2012; McMichael 2012). These recent studies have been important in identifying some of the key forces and actors involved in this process, and signal the need for further investigation of the role of financial actors in the food system to tease out its specific implications.

In addition to shaping the food regime by providing new avenues for accumulation, the specific dynamics of financialization - the types of actors involved and the characteristics of the new financial tools they utilize-also affect food politics in other ways by shaping the political context for resistance. By adding new and highly complex financial relationships within the food regime, the precise role of financial actors and the consequences of their investments on the ground have become more opaque, making political action to address it more challenging. The concept of distance can help to shed light on light on this impact of financialization. Distance in global commodity chains refers to the separation between production and consumption decisions (Friedmann 1994; Kneen 1995; Princen 1997; 2002; Clapp 2012). As Freidmann notes, distance has become a dominant norm as food systems have become more globalized, which in turn has suppressed the particularities of both time and place in agriculture as well as diets, with important implications for politics (Friedmann 1994, p.379). Princen shows that distance in global commodity chains can occur along several dimensions, including geography (physical distance), culture (knowledge about the conditions of production), bargaining power (ability to drive decisions) and agency (the number of middlepersons in a commodity chain) (Princen 2002). Kneen notes that technological change also expands distance by separating raw food from the final product (Kneen 1995). Greater distance between the point of production and consumption tends to constrain information feedback concerning the social and ecological implications of production processes and economic relationships at different points along 
commodity chains (Kneen 1995, p.25; Princen 1997; Dauvergne 2008). With multiple middlepersons typically present within commodity chains that span across greater geographical distances, for example, opportunities are opened up for some agents to wield more bargaining power and withhold information that ultimately severs feedback loops which would normally make clear the lines of responsibility to protect a resource (Princen 2002, p.122-23).

The way in which distancing constrains information feedback is important for the political context. When distance expands as more actors enter the chain, powerful actors are also more likely to externalize or shade costs, rendering them 'invisible' to others (Princen 2002; Kneen 1995). Environmental problems can then be easily displaced and consumers are left largely unaware of the full ecological and social consequences of their own consumption (Princen 1997; 2001; 2002, p.108-115; Dauvergne 1997; 2008). The shading of costs also blurs the lines of responsibility for addressing them. Dauvergne argues that elongated commodity chains in the current era of economic globalization are particularly problematic because the uneven global trade, investment and finance relationships fuels myriad environmental and social consequences in different locations around the world, with the costs typically falling disproportionately on the world's poor (Dauvergne 2008, p.10). In such cases, the politics of resisting these forces and addressing the costs is fraught with challenges (Princen 2002, pp.123-30; Dauvergne 2008 p.210). Corporate actors can exploit the obscured nature of their own role in externalizing costs by developing competing discourses that aim to shape or reshape the way people view their activities in a positive light (See Fuchs 2007; Clapp and Fuchs 2009).

These conceptual insights from the broader literature on distancing help to illuminate political dynamics emerging within a more financialized food system. To start, it can be noted that financialization drives distancing within the food system in two key ways, each of which shape the broader political context. First, new actors and their vast financial resources are brought into the food system, changing the boundaries of agrifood commodity chains as more decision points are added from production to consumption. Financial investors may not be directly involved in production and marketing of actual food products, but they have gained bargaining power around the edges of the physical agrifood commodity chains through the provision of funding, the extraction of profits, and their broader influence over market and price trends (Burch and Lawrence 2009). Although financial investors have had a long relationship with agricultural commodity markets, financial deregulation in the sector has enabled large numbers of investors, operating through banks and financial subsidiaries of trader firms, to enter these markets en masse. Because of their sheer size, investors now wield enormous influence over market conditions, and ultimately prices, of food commodities.

Second, financialization drives a new kind of distancing by encouraging a greater abstraction of agricultural commodities from their physical form. As the rules governing agricultural commodity markets became more relaxed (see below), the use of new and more intricate financial derivatives proliferated (Burch and Lawrence 2009). These products are designed as 
financial investments, to give investors an opportunity to gain exposure to commodities in order to diversify their financial portfolios, but without having to purchase the physical commodities. For these investors, agricultural derivatives are attractive for the financial opportunities that they offer. The virtual dimension of the product takes on its own value and can generate profits, even though the investor does not own, or have any need for, the physical commodity with which it is associated. In this way, investment in the commodity is separated from its physical form. Yet at the same time, these new agricultural derivatives are locked to physical markets in new and complex ways, and trends in one market affect trends in the other (Russi 2013).

These new kinds of distancing associated with financialization-involving both an increased number of players in the commodity chain as well the abstraction of physical commodities to a new financial form-in turn have important implications for the politics of food. These forms of distancing in the food system, not unlike greater distancing in other commodity chains, have an obscuring effect that shapes the political context (Princen 2002). In this case, financial investments fuel activities that often result in negative social and environmental effects on a global scale, yet those costs are often externalized, or shaded. The increase in the number of financial agents involved in and around agrifood commodity chains constrains information feedback, which makes cost externalization easier and more likely. As a result, the ways in which the global financial system is linked to outcomes in the food system-in particular when negative social and environmental costs occur-is not always clear. The activities of financial institutions and investors are often taking place virtually in financial centers concentrated in the world's wealthiest countries, often well before commodities are grown or delivered, and often at a great physical and cultural distance from the point of production. Banks and financial investors are buying and selling products based on agricultural commodities, and influencing the global food system in ways that are not always visible to the general public. This lack of clarity creates opportunities for competing narratives, or discourses, to emerge that seek to explain the negative outcomes in ways that portray financial actors as providers of solutions rather than sources of problems. The result of both new forms of distancing and the emergence of competing discourses presents a challenging political context for civil society organizations that are seeking to oppose financialization in the global food system.

\section{Agriculture as Financial Investment}

The link between financial investors and agricultural commodity trade has existed for centuries (Bryan and Rafferty 2006). Futures exchanges for agricultural commodities were established in London, for example, in the $18^{\text {th }}$ century. Futures markets provided a means by which farmers and grain merchants could purchase and sell agricultural commodities for delivery at a future date. The ability to make deals in the 'future' enabled both sellers and buyers to lock in prices and hedge their risks in a sector that is highly uncertain due to weather fluctuations and the perishability of foodstuffs. As such, these markets have played an important role in 'price discovery' for commodities. Financial investors speculating on price movements in these early 
futures markets by provided liquidity in cases where farmers and end-users did not find equal matches for their needs. More institutionalized commodity futures trading markets emerged in other UK cities and in the United States by the mid-1800s and the practice of commodities futures trading became widespread (Cronon 1991). The ability to hedge their positions in the grain markets enabled large grain trading companies to expand their scope and size in the latter part of the $19^{\text {th }}$ century (Morgan 1979).

The possibility that speculators might manipulate markets by taking large positions was recognized early on. Because of this risk, agricultural futures markets in the United Stateshome to the largest agricultural commodity futures exchange, the Chicago Mercantile Exchange Group - have been tightly regulated since the early 1900s. The 1922 Grain Futures Act mandated that all futures trading had to take place on approved exchanges that outlawed price manipulation. Since 1923 daily reporting on trading by market traders in the markets was required. The 1936 US Commodity Exchange Act gave US federal regulators the authority to establish 'position limits' on those traders who were deemed to be 'non-commercial'; that is those not involved in the business side of the commodity as either farmers, grain elevator operators, or end-users such as commodity firms and food processors. These non-commercial traders were not seen as bona fide hedgers in the markets. Rather, they were viewed as financial speculators, and the number of futures contracts there were legally allowed to hold at any time was strictly controlled. The aim of the legislation was not to outlaw speculation, but rather to prevent 'excessive' speculation that might result in market manipulation and sudden sharp price shifts (US Senate 2009; Clapp and Helleiner 2012a). Since 1974, the Commodity Futures Trading Commission (CFTC) has maintained regulatory oversight of commodity futures markets in the US, including monitoring of position limits.

\section{Banks See Opportunity in Agriculture}

The above regulations were put in place to prevent market manipulation and sharp price shifts. But those regulations began to be relaxed in the 1980s and 1990s (Ghosh 2010). In response to pressure from some large banks to relax the tight position limits for non-commercial operators, the CFTC issued what were referred to as 'no action letters.' These letters enabled specific banks that requested them to exceed position limits on the grounds that their positions in commodity markets were hedges against real risks they faced in financial markets. Banks needed to hedge their own financial risks by engaging in physical markets in large quantities because they began to sell financial derivative products to investors that were based on agricultural commodity markets (Clapp and Helleiner 2012a).

A common financial derivative that banks began to sell is known as a 'commodity index fund' (CIF). These derivative products track changes in the prices of a bundle of different types of commodities as an index (Kaufman 2010). A general commodity index is made up of the prices of agricultural commodities, minerals, livestock and petroleum products. Agricultural products 
typically make up around one third of the value of these indices. What the CIF offers investors is an opportunity to gain exposure to commodity markets without being required to purchase the actual commodities on exchanges. The most popular of these index funds are the Standard and Poor's Goldman Sachs Index and the Dow Jones AIG Index (IATP 2008, DeSchutter 2010). In selling these products, the banks act as middle operators, providing a financial derivative product based on commodity markets to investors 'over the counter' (OTC), meaning that it is a nonstandardized derivative contract and thus cannot be traded on an open exchange, but rather is arranged informally (Russi 2013, p.47). At the same time, the sale of these financial products posed a financial risk for banks that sold them. If commodity prices in the index rose, they would have to pay out returns to investors. To hedge these new financial risks, the banks began to purchase actual commodity futures contracts on commodity exchanges, so that they would actually gain financially if prices rose, and thus be able to make the payments to investors. This need to invest in the commodity futures markets was precisely why these banks pressed for a relaxation of position limits (Clapp and Helleiner 2012). The new rules enabled them to expand the sale of OTC agricultural derivatives products to investors who themselves were unable to participate directly in commodity exchanges. But the OTC products and commodity exchanges became linked because banks operated in one to hedge their risks in the other.

In 2000, the relaxation of regulations was codified with the passage of the Commodity Futures Modernization Act (CFMA) in the US (Ghosh 2010). This law exempted OTC derivative trading from oversight by the CFTC (Tett 2009). In effect, the sale of OTC derivatives products was not regulated, and purely speculative trading in these types of derivatives products was allowed. This deregulation in the United States, the most tightly regulated commodity futures markets, brought it more into line with markets in other countries. The EU, for example, had only light regulations on its commodity futures market, and prior to 2008 placed no regulations on OTC derivatives trading (Vander Stichele 2011, p.1).

Other kinds of financial investment products linked to the agricultural sector also began to be offered by banks after 2000, including funds that invested not just in commodities, but also farmland and agriculture-based firms (Burch and Lawrence 2009, pp.271-2; McMichael 2012, pp.688-91; White et al.2012; Daniel 2012). Buying a stake in farmland provides financial investors exposure to the agricultural production that underlies commodity prices. And investment of this kind has been made both more attractive, and easier, by the increased financialization of food and agriculture. It is attractive because the exposure to farmland expands investors' opportunities to earn returns from the production of food and biofuel crops in a context where both financial and commodity markets (including fossil and biomass energy) are increasingly volatile and uncertain, but also inextricably linked (White and Dasgupta 2010; McMichael 2012; Clapp and Helleiner 2012b). The involvement of financial investors in farmland has also been made easier by the development of financial derivatives that are based on land investment (Burch and Lawrence 2009; McMichael 2012). Some of new agriculture funds specialize in farmland acquisition, and some 66 funds now include land in their portfolio 
(Buxton et al. 2012, p.1). BlackRock, for example, an investment firm that is the world's largest manager of assets, established a World Agriculture Fund in 2010 that invests in a range of agriculture-based assets, including commodity futures, farmland, agricultural input firms, and food processing and trading companies, which it bundles into an index (BlackRock 2012). Agriculture-based exchange-trade funds (ETFs) have also emerged, including the DaxGlobal Agribusiness Index and the Dow Jones Global Equity Agriculture Index. These funds track the performance of the largest agricultural firms and sell shares on the stock exchange. According the International Institute for Environment and Development, around 190 private equity firms are acquiring land and other agricultural assets on behalf of their investors (Buxton et al. 2012).

\section{Commodity Trading Firms Deepen the Linkage}

Banks were not the only financial actors to capitalize on the changing face of commodity futures markets that resulted from changes to regulations. Tapping into rising investor demand for commodity derivative financial products, the large agricultural commodity trading firms also began to get into the business. Archer Daniels Midland (ADM), Bunge, Cargill and Louis Dreyfus - known in the business as the ABCD firms - are heavily engaged in the agricultural derivatives market. Each of these firms has a long history: Bunge dates back to the early 1800s, Cargill to the 1860s, Dreyfus to the 1880s, and ADM to the early 1900s (Morgan 1979). The ABCD firms operate under a complex business model that involves dealing in bulk commodities and trading high volumes at typically low margins. Each of these firms is intimately linked to the world of complex agricultural commodity chains, with different aspects of their business touching all aspects of those chains from production to consumption. And each has privileged access to information that has helped them to maintain advantage over their competitors (Murphy et al. 2012).

The commodity trading firms have long used their information advantage to manage their own business risks by purchasing and selling agricultural commodity futures contracts on commodity exchanges (see Kneen 2002; Morgan 1979). In some cases, these firms are engaged in hedging of their own business operations. But it is virtually impossible to tell when these firms are instead making purely speculative investments based on their own inside knowledge of agricultural commodity markets. As the Wall Street Journal noted in 2009, "In contrast to stocks, commodities trading is the only major U.S. market where companies are allowed to act on inside information to manage risks others might not know about” (David 2009). Commodity trading firms are often the first to become aware of crop shortages or other interruptions to agricultural trade, giving them an information advantage in the futures markets (Meyer 2011).

Commodity trading firms were able to capitalize on their specialized knowledge of the sector and in the past two decades have made financial and risk management a major part of their business structure (Murphy et al. 2012). In this period, each of the ABCD companies established financial subsidiary firms that specialized in this task. The ABCD financial services firms gradually began 
to meet not just their own risk management needs, but also those of third party investors. The financial arms of these firms became very active in selling OTC derivatives, much like the banks were doing. Cargill, for example, founded Cargill Risk Management (CRM) in 1994, explicitly to sell individualized OTC products for its own purposes and for third party customers. In 2003, Cargill established another independently managed subsidiary, Black River Asset Management, which started to manage the funds of third party investors in 2004. ADM operates ADM Investor Services (ADMIS), a subsidiary which also sells OTC agricultural derivatives to third parties and which has two separate financial subsidiaries that operate under it, selling investment products to business partners and third party institutional investors. Louis Dreyfus established two agricultural hedge funds: the Alpha Fund that specializes in agricultural commodities and Calyx Agro that specializes in farmland investments in Latin America. Bunge has two financial divisions, Bunge Global Markets and Bunge Limited Finance Corporation (Murphy et al. 2012).

The distinction between banks and commodity trading firms has become increasingly blurred since the mid 1990s as both sets of actors became actively engaged in selling OTC agricultural commodity derivatives products such as commodity index funds and other OTC financial derivative products (Burch and Lawrence 2009, p.277). The market for these products grew rapidly after 2000 when the CMFA came into place, and the total assets of financial speculators in agricultural commodity markets increased from US\$65 billion in 2006 to some US\$126 billion by early 2011 (Worthy 2011, p.13). Much of this increase is due to financial speculation. In the US wheat futures market, for example, financial speculators' share of the trade increased from 12 percent in the mid-1990s to 61 percent in 2011 (Worthy 2011, p.13).

\section{Large-scale Third Party Investors}

In this period, agriculture-based financial investment products became hugely popular among investors, including large-scale institutional investment funds and wealthy individuals.

Institutional investors include insurance companies, pension funds, mutual funds, sovereign wealth funds, hedge funds, and university and foundation endowments. These investment funds essentially pool resources of those that invest in them, enableing them to expand and diversify their investment options while sharing transaction costs (Burch and Lawrence 2009, pp.272-3; Buxton et al. 2012). According to the Bank for International Settlements, in 2005, insurance companies, pension funds, and mutual funds together managed US\$46 trillion (BIS 2007). These large-scale investors have some unique features, one of which is that they tend to be passive investors with a significant proportion of their investments. With large amounts of money to invest, they tend to make long-term investment decisions that do not require active management, and members do not always have detailed knowledge of their own investments.

Large-scale financial investors increasingly began to seek exposure to commodities as an asset class after 2000, as commodity prices in general were rising in this period (Burch and Lawrence 2009, p.273). Food and energy commodities in particular saw important upward price shifts, as 
these sectors became increasingly locked together through the rise of biofuels as an alternative energy source and financial derivatives that bundled food and energy commodites together (Clapp and Helleiner 2012b; McMichael 2010). Investors sought to purchase financial products from large banks and the financial arms of commodity trading firms who offered exposure to commodities and farmland through CIFs and other kinds of agriculture-based financial investments that were becoming more readily available to them. Some estimates put overall commodity investments of institutional investors at around US\$320 billion, which is up significantly from the US\$6 billion they held in investments in this sector in 2002 (Buxton et al. 2012, p.2).

Institutional investors are also increasing their exposure to farmland via new derivative products on offer from large investment banks and commodity firms (Daniel 2012). Farmland is especially attractive to institutional investors because it not only holds value in itself due to its limited supply, but also produces a flow of income from the production that arises from it. These traits suit investors with long time horizons, such as pension funds, that seek to capitalize on rising demand for food and biofuels on a fixed land base. BlackRock's World Agriculture Fund noted above, for example, markets to institutional investors and includes agricultural land in its fund (Black Rock 2012). Pension funds have been actively adding farmland to their asset mix, holding approximately US\$5-15 billion in farmland assets (GRAIN 2011). The Calyx Agro fund, noted above, explicitly seeks to identify, acquire, develop, concert and sell farmland for large institutional investment funds such as AIG, with a focus on Latin America.1 Private equity funds EmVest and SilverStreet Capital have established funds that target institutional investors and focus specifically on African farmland (Daniel 2012, pp.705-706).

This closer look at the regulatory trends and the actors involved in financialization in the food system illustrates the ways in which distancing has expanded. Deregulation has enabled the entry of new actors, or middlepersons, into agrifood commodity chains. Banks, institutional investors, and new financial investment arms of the ABCDs are now active participants in agrifood supply chains, bring with them considerable decision-making power based on their financial weight. Along with new actors, new types of relationships between actors, in the form of abstract commodity derivatives, have also changed the shape and culture of those commodity chains. Financial investors are not necessarily buying agricultural commodities in their physical form, but rather are seeking profits in and around the commodity chain, through new kinds of financial derivatives that are abstractions from the physical commodity. CIFs, in particular, have been especially attractive for the needs of these large-scale third-party investors. They are easy to obtain because they are sold OTC, and investors can hold them for long periods of time, waiting to reap profits as commodity prices climb. The pooling of financial resources of multiple investors and the availability of new financial products also enables institutional investors to buy

1 See Calyx Agro website: http://www.calyxagro.com/company.php and Henriques 2008. 
a stake in farmland and other land-based derivatives. These changes brought by financialization have important implications for the politics of food, as discussed below.

\section{Financialization and the Political Context for Opposition}

Increased distancing that has resulted from financialization has worked to obscure the role that financial investors play in driving certain outcomes in the global food system. The increased number of financial actors in the agrifood sector and the introduction of new and complex agricultural derivatives have made the boundaries around commodity chains, and the lines of responsibility within them, less clear. This new context complicates political action around food. Some analysts have linked rising financial speculation in agricultural commodities and land to food price volatility and speculative land grabs, each of which imposes social and ecological costs in the world's poorest countries (e.g. Ghosh 2010; Dauvergne and Neville 2010; White et al. 2012; McMichael 2012; Daniel 2012; Russi 2013). But distancing, as outlined above, has made the precise impact of each financial investment hard to pinpoint with certainty because the flow of information is inhibited by greater distance that financialization has brought to the food system. Financial investors' funds are often pooled and managed by others, which in turn makes drawing a causal link between particular financial investments and their potential negative outcomes, such as hunger or environmental degradation in specific locations, extremely difficult (Clapp and Dauvergne 2011, p.217). The new forms of distancing, in other words, have expanded the opportunity for powerful agents within commodity chains to shade costs.

The difficulty of drawing a direct causal line from financial investments to outcomes in the food system has made the political context much more challenging for civil society organizations campaigning on these issues. Although there are growing pressures for progressive reform in the food system in the face of crisis (e.g. Giménez and Shattuck 2011), the lack of certainty about the specific impact of financial actors caused by distancing creates room for competing narratives that feature other, non-financial explanations for hunger, displacement from land, and environmental degradation. Instead of seeing the rise in financial investment in agriculture as a potential problem, other narratives in fact often portray financialization as a solution to problems in the food system. These narratives typically emanate from financial actors themselves as well as powerful organizations that support them. The World Bank, for example, has played a key role in advocating for more commodity exchanges in developing countries at the same time that it has portrayed large-scale land acquisitions as an important development opportunity (Bush 2012; World Bank 2007; 2010).

Both the new forms of distancing, and the competing discourses they give rise to, complicate efforts of civil society organizations that are seeking to curb the effects of financial actors in the food system. In this political context, the typical response of states has been to adopt weak regulations. These trends can be illustrated through a very brief overview of the recent politics surrounding food price volatility. 


\section{Uncertainty and Debate Over Role of Finance in Driving Food Price Volatility}

It is widely understood that financialization in the food sector has exposed agricultural prices to broader trends in financial markets (Kaufman 2010; Russi 2013). As noted above, financial market turmoil after 2006 contributed to disruptions in food markets that encouraged investors to capitalize on commodities that were at that time widely advertised to be a more stable and higher-return investment than other kinds of financial derivatives. As money poured into commodities in large amounts in this period, food prices began to climb. In the 2006-2008 period, average world prices for rice rose by 217 percent, wheat by 136 percent, maize by 125 percent and soybeans by 107 percent (WRI 2008). But by the end of 2008, prices fell just as dramatically as financial markets collapsed and investors retreated. Volatility and renewed price spikes then returned in 2010-12. Fluctuating food prices on world markets in this period have caused enormous disruptions to food security of the world's poorest people (FAO 2011; Daivron et al. 2011; IFPRI 2011). Most analysts agree that there is some link between the recent rise of financial speculation in commodity markets and food price trends. But because distancing has obscured the precise lines of cause and effect, the extent to which financial speculation is viewed as central cause of food price volatility or a marginal force is highly contested. In other words, distancing has fuelled uncertainty about cause, effect and responsibility, giving rise to competing discourses about the issue.

When food prices rose steeply after 2006, a number of analysts and civil society organizations pointed to speculative finance as a driving factor. Bolstered by the FAO's analysis that a significant portion of the price volatility was well beyond what would be explained by underlying supply and demand for food (FAO 2008), these analysts made the case that the fundamentals of supply and demand alone could not explain the food price spikes (Mittal 2009). They argued that speculation was the only plausible explanation, and that it drove up food prices and made them more volatile as financial speculators moved in and out of commodity derivatives in order to seek profits as financial market conditions changed (e.g. IATP 2008; Ghosh 2010; Kaufman 2010; Russi 2013). Speculative investment in CIFs was blamed in particular for pushing up food prices. Even though they are only indices of prices on commodity markets, large movements of speculative capital into these particular financial products can cause severe disruptions to commodity markets (Masters 2008). As institutional and other investors purchase index funds, banks and commodity trading firms hedge the risks associated with the sale of those products on commodity futures markets, in effect linking the physical market with the index. And although they are betting huge sums on the physical commodity futures market, these transactions are in the hands of relatively few traders. At the height of the food price rises of 2008, just six traders held up to 60 percent of the Chicago wheat futures contracts that were linked to index funds (US Senate 2009). In this context, critics argued, even very small changes in how investment portfolios of thousands of investors are managed can result in sharp changes in agricultural prices. Several recent studies that have presented sophisticated models teasing out 
the different factors that have affected commodity price volatility point to financial speculation as a significant force (Lagi et al. 2011; Basak and Pavlova 2013).

Others have taken issue with these lines of argument, inserting a competing narrative into the space obscured by distancing. The World Bank and OECD, for example, have presented highly technical arguments about the functioning of futures markets that downplay the idea that financial speculation fuels food price volatility (World Bank 2008, Irwin and Sanders 2010). Supporters of this view have made the case that there is little evidence to prove that causal link and they suggest that critics of financial speculation have misunderstood the technicalities of how the markets work (Irwin et al. 2009). For these analysts, commodity futures markets have provided liquidity and capacity to absorb risk to global food markets in ways that have instead helped to stabilize food prices (Irwin et al. 2009; Sanders and Irwin 2010). From this standpoint, the primary causes of food price volatility can be found elsewhere, namely fundamentals of supply and demand in food markets themselves (Irwin et al. 2009).

The debate over the impact of commodity speculation on food prices continues. By 2010, it was clear that food price volatility was persisting, and pressure grew to uncover the cause. The G20 announced that it was taking up the issue under France's leadership the following year. Around this time, several international organizations began to stress that speculation in agricultural commodity futures markets and financial derivatives was a factor in at least exacerbating price volatility trends. The Bank for International Settlements noted, for example, that financialization influences commodity prices, especially in the short term. Several UN reports also came to a similar conclusion (BIS 2011, De Schutter 2010, UNCTAD 2011). An UNCTAD report explains that investors often act in a herd-like fashion, following each other due to the lack of perfect information. This herd behaviour can make prices swing up and down more dramatically than they otherwise would have done (UNCTAD 2011). Although these reports provided some fuel to those seeking greater regulation of financial markets to stem excessive commodity speculation, progress on this front has been slow and uneven, indicating that the debate on the role of finance in food price volatility is far from settled (Clapp and Murphy 2013).

\section{Civil Society Campaigns and Financial Sector Backlash}

A number of civil society groups concerned about the impact of food price volatility on hunger have sought to challenge the new role of financial actors in the food system by calling for divestment from speculative activities that drive up food prices and for stronger state-based regulation to curb speculation on food. The new types of distancing brought about by financialization, however, have made the political context within which these groups operate more difficult in several ways. First, these groups have had to engage with a large number of new actors in the agrifood commodity chain, namely financial institutions, which they previously had not dealt with in any extensive way. Second, the abstract nature of agricultural financial derivatives has complicated the general public's understanding of the issue and meant that 
campaigners have to become knowledgeable about a highly technical sector in a very short period of time. And third, because these types of distancing created room for the emergence of competing narratives about the causes of food price volatility (as outlined above), civil society groups face the challenge not only of explaining their concerns to the general public, but also of constantly engaging with these alternatives narratives in order to ensure that their message was not undermined.

Although distancing brought by financialization introduced these new political challenges, civil society organizations were not deterred from launching campaigns that sought to shine a light on the role of financial actors in fuelling food price volatility. As the G20 took up the issue of food price volatility in 2010-11, a number of organizations based in Europe, including World Development Movement, Oxfam, and Friends of the Earth, and Foodwatch, launched campaigns that sought to stop banks' participation in agricultural commodity speculation and to improve financial sector regulation (Jones 2010; Worthy 2011, Herman et al. 2011; Friends of the Earth Europe 2012; Foodwatch 2011). In the US, a coalition of groups launched the Stop Gambling on Hunger campaign, including the Institute for Agriculture and Trade Policy, Better Markets, and Commodity Markets Oversight Coalition (CMOC).2 An open letter posted on the World Development Movement website has been signed by over 100 civil society groups which allied in a broader global campaign to "stop gambling on food and hunger" (WDM 2011). Many of these groups targeted large banks familiar to the general public that deal in agricultural commodity derivatives. The World Development Movement, for example, has targeted Barclays Bank and Goldman Sachs, while Oxfam France and Foodwatch focused their attention on major banks in France and Germany respectively (e.g. Scott 2011; Foodwatch 2011; Oxfam France 2013).

Some successes have been won by these groups, but given the complex political environment in which these campaigns were launched the overall outcome has been mixed and the successes are fragile. In the first half of 2012, several German and Austrian banks, including Deutsche Bank, announced that they would be removing agricultural products from their index fund products. In early 2013, several major French banks pulled out of commodity speculation in direct response to an Oxfam France report that targeted them (Oxfam International 2013). And in the UK Barclays announced in early 2013 that it too would be withdrawing from speculation on food prices (Treanor 2013). By mid-2013, the WDM reported that some 11 European banks had pulled out of financial investment in agricultural commodities.3

But the WDM also warned that these banks could chance course at any time. Indeed, one major financial institution that had halted agricultural commodity speculation in 2012, Deutsche Bank, has already reversed its decision, announcing it was reinstating its agricultural commodity

2 See http://stopgamblingonhunger.com)

3 See http://www.wdm.org.uk/category/tags/food-speculation 
investments. On making this announcement, the bank invoked the competing narratives cited above, arguing that it found "no convincing evidence” that financial speculation in agricultural commodity markets had driven up food prices or made them more volatile (Deutsche Bank 2013). Lobbyists for the banks have also become more aggressive in trying to shape the public debate on the issue by taking advantage of the uncertainties about the cause and effect generated by distancing. The International Swaps and Derivatives Association (ISDA), an association representing over 800 financial institutions including Barclay’s, Deutsche Bank, JP Morgan, Goldman Sachs and Morgan Stanley, among others, launched a website in early 2013 that counters growing criticism of commodity speculation by selectively reproducing quotes from reports and media appearances of analysts who argue that financial speculation is not a cause of price volatility and that financial reform to address it is not needed.4 Civil society groups in turn have coordinated their own efforts more tightly and have filled their own websites not just with their own studies, but those of other groups, academics, and policymakers that agree with their assessment of the role of speculation in causing food price volatility. But it has often been challenging to present to the general public what are often quite technical debates about the impacts of the abstract financial products involved.

In addition to targeting specific financial institutions to demand divestment, civil society organizations have also worked to strengthen financial regulation to stem commodity speculation. To engage in these debates, these groups had to learn the highly technical details of abstract financial derivatives as well as the complex regulatory context. The outcomes, once again, have been mixed. The 2008 food and financial crises generated significant political momentum to reform its financial market regulations, including demands from civil society lobby groups such as the CMOC for tighter position limits and improved reporting in commodity derivative markets (Clapp and Helleiner 2012). After long and hard-fought struggles, the 2010 Dodd-Frank Wall Street Reform and Consumer Protection Act did in back stronger measures to limit speculation in agricultural commodities, calling upon the CFTC to put in place more stringent position limits and more rigorous and transparent reporting of over-the-counter trades, among other things.

But the implementation of Dodd Frank has been slow and uneven, raising concerns about its long term fate. In late 2011 the CFTC was faced with a legal challenge from ISDA and the Securities Industry and Financial Markets Association over its rules concerning position limits (Protess 2011). These lobby groups made the case that the rules should not be implemented because the CFTC moved ahead to impose position limits without first determining whether those limits were either 'necessary' or 'appropriate.' Because distancing obscures the lines of cause and effect, the implementation of the act was easily contested. Weeks before the rules were due to be implemented in 2012, the court ruled that the CFTC failed to prove that such rules were

4 See $\underline{w w w . c o m m o d i t y f a c t . o r g . ~}$ 
'necessary', and as such the rules did not come into place. The CFTC appealed the ruling and the case is still in the courts (Protess 2012; Schoenberg 2012).

Civil society groups are also lobbying policymakers in Europe to impose position limits and more comprehensive reporting on commodity derivatives markes as part of financial market reforms under the EU Markets in Financial Instruments Directive (MiFID). As in the US case, however, opponents of reform have capitalized on the obscured role of financial actors caused by distancing. Like their US counterparts, these opponents have called into question the causal relationships drawn by the civil society groups, thereby weakening the momentum behind the reform efforts. Civil society groups have expressed strong concern about the direction of the negotiations (Friends of the Earth 2013). Even if the European Union does tighten regulation in this area, implementation of the new rules is very likely to meet with further resistance by the financial industry, as has been the case in the US.

From this very brief review of the recent campaigns against agricultural commodity speculation, it is apparent that the results have been mixed, and the political context remains a complicated one. Although some financial institutions have chosen to withdraw from financial speculation on food prices, other banks and lobby groups have fought back and are seeking to shape public discourse toward a more positive view of the impact of agricultural commodity speculation by financial actors. Progress on financial regulatory reforms in the US and EU has also been slow and uneven. The campaigns have required civil society groups to engage with new financial actors and financial regulatory issues. Distancing has also obscured the impact of financial investments on the global food system in ways that complicate the efforts of campaigners to engage the general public and that open the door for competing campaigns to undermine campaigners' goals.

\section{Conclusion}

Financialization in the food system has added a layer of complexity to agrifood markets in recent years. New financial actors have entered agrifood commodity chains and have acquired significant power within them through the use of new complex financial derivative products. But the influence of these actors and the outcomes of their investments are not always transparent because of the distancing that financialization has also generated. Financialization has contributed to greater distancing within the food system by facilitating the entry of new actors taking profits along in and around agrifood commodity chains, and by encouraging more abstraction of the commodity from its original form, in this case into a 'virtual' financial derivative product.

By obscuring the cause and effect of financial investment activities from public view, distancing increases opportunities for ecological and social costs to be externalized on a global scale. With many more financial actors now involved in and around the edges of the agrifood supply chain, 
and with their investments in a mix of abstract financial derivatives and pooled investment funds linked to food commodities, agriculture and farmland, it is difficult to ascertain the precise role of specific investors in driving the negative outcomes as well as the lines of responsibility for addressing them. This lack of clarity on the role of finance has complicated the efforts of civil society groups to engage the general public and has opened spaces for counter-narratives to emerge over the role of financial actors in fuelling the problem. In this challenging political environment, it is not surprising to see only slow and uneven progress.

The analysis in this paper contributes to the broader literature on financialization as well as more recent work on the financialization of food by showing how the specific dynamics of financial markets contribute to distancing in the global food system, which in turn affects the political context for resistance to the growing power of financial actors within that system. The paper also contributes to the conceptual literature on distancing by highlighting the way in which financialization fosters new forms of distancing, in particular through abstraction of food from its physical to a financial form. It also shows that distancing is important to examine not just in terms of its implications for production and consumption decisions, but also how it affects investment decisions that have crucial implications for social and ecological outcomes relating to both production and consumption.

\section{Acknowledgements}

For helpful comments and advice, the author would like to thank Kimberly Burnett, Rachael Chong, Taarini Chopra, Eric Helleiner, Sarah Martin, Sophia Murphy, and Jan Aart Scholte, and three anonymous reviewers.

\section{References}

BIS. 2007. Institutional Investors, Global Savings and Asset Allocation. CGFS Paper 27. Committee on the Global Financial System. Basel: Bank for International Settlements

BIS. 2011. 81 ${ }^{\text {st }}$ Annual Report. Basel: Bank for International Settlements. Available from: http://www.bis.org/publ/arpdf/ar2011e.pdf [Accessed 8 July 2013].

Basak, S. and A. Pavlova. 2013. A model of financialization of commodities. Available from: http://ssrn.com/abstract=2201600 [Accessed on].

BlackRock. 2013. BlackRock World Agricultural Fund Fact Sheet. May. Available from: http://www.blackrock.com.hk/content/groups/hongkongsite/documents/literature/1111121111.pd f [Accessed 8 July 2013] .

Bryan, D. and M. Rafferty. 2006. Capitalism with derivatives. Basingstoke: Palgrave Macmillan. 
Burch, D. and G. Lawrence. 2009. Towards a third food regime: behind the transformation. Agriculture and Human Values, 26(4), 267-279.

Bush, S.B. 2012. Derivatives and development. New York: Palgrave Macmillan.

Buxton, A., M. Campanale and L. Cotula. 2012. Farms and funds: investment funds in the global land rush. IIED Briefing. January. London: IIED. Available from:

http://pubs.iied.org/pdfs/17121IIED.pdf [Accessed 8 July 2013].

Clapp, J. 2009. Food price volatility and vulnerability in the Global South: considering the global economic context. Third World Quarterly, 30(6), 1183-1196.

Clapp, J. 2012. Food. Cambridge: Polity.

Clapp, J. and D. Fuchs, eds. 2009. Corporate Power in Global Agrifood Governance. Cambridge, MA: MIT Press.

Clapp, J. and P. Dauvergne. 2011. Paths to a Green World. Cambridge, MA: MIT Press.

Clapp, J. and E. Helleiner. 2012a. Troubled futures? The global food crisis and the politics of agricultural derivatives regulation. Review of International Political Economy, 19 (2) 181-207.

Clapp, J. and E. Helleiner. 2012b. International political economy and the environment: back to the basics? International Affairs, 88(3), 485-501.

Clapp, J. and S. Murphy. 2013. The G20 and food security: a mismatch in global governance? Global Policy, 4(2), 129-138.

Cotula, L. 2012. The international political economy of the global land rush: A critical appraisal of trends, scale, geography and drivers, The Journal of Peasant Studies, 39 (3-4), 649-680.

Cronon, W. 1991. Nature's metropolis: Chicago and the Great West. New York: W. W. Norton \& Company.

Daniel, S. 2012. Situating private equity capital in the land grab debate. Journal of Peasant Studies, 39(3-4), 703-729.

Daniel, S. and A. Mittal. 2011. The Great Land Grab: Rush for the world's farmland threatens food security for the poor. Oakland Institute: Oakland, CA.

David, A. 2009. Cargill’s inside view helps it buck downturn. Wall Street Journal, 14 Jan.

Dauvergne, P. 1997. Shadows in the forest: Japan and the politics of timber in Southeast Asia. Cambridge, MA: MIT Press.

Dauvergne, P. 2008. The shadows of consumption. Cambridge, MA: MIT Press.

Dauvergne, P and K. J. Neville. 2010. Forests, food, and fuel in the tropics: the uneven social 
and ecological consequences of the emerging political economy of biofuels. The Journal of Peasant Studies, 37(4), 631-660.

De Schutter, O. 2010. Food commodities speculation and food price crises. UN Special Rapporteur on the Right to Food. Briefing Note 02 - September. Available from: http://www.srfood.org/images/stories/pdf/otherdocuments/20102309_briefing_note_02_ee_ok.p df [Accessed 8 July 2013].

Deutsche Bank. 2013. Questions and answers on investments in agricultural commodities. Frankfurt: Deutsche Bank. Available from: https://www.db.com/en/content/company/headlines_agricultural_commodities_faq.htm [Accessed 8 July 2013]

Engelen, E. 2008. The case for financialization. Competition \& Change, 12 (2), 111-119.

Epstein, G. 2005. Introduction: financialization and the world economy. In: G. Epstein, ed. Financialization and the world economy. Cheltenham: Edwar Elgar, pp. 3-16.

FAO. 2011. The state of food insecurity in the world 2011. Rome: Food and Agriculture Organization.

FAO. 2008. Food outlook. June. Rome: Food and Agriculture Organization. Available from: ftp://ftp.fao.org/docrep/fao/010/ai466e/ai466e00.pdf [Accessed 8 July 2013]

Foodwatch. 2011. The Hunger-Makers: how Deutsche Bank, Goldman Sachs and other financial institutions are speculating with food at the expense of the poorest. Berlin: Foodwatch.

French, S., A. Leyshon, and T. Wainwright. 2011. Financializing space, spacing financialization. Progress in Human Geography, 35(6), 798-819.

Friends of the Earth. 2013. MiFID2: set to fail on food speculation. Policy briefing. April. Available from:

https://www.foeeurope.org/sites/default/files/makefinancework_mifid_loopholes_june2013.pdf [Accessed July 8 2013]

Friedmann, H. 1994. Distance and durability: shaky foundations of the world food economy”, in P. McMichael, ed. The Global Restructuring of Agro-Food Systems. Ithaca: Cornell University Press, pp.258-276.

Fuchs, D. 2007. Business power in global governance. Boulder, CO: Lynne Rienner Publishers.

Giménez, E.H., and A. Shattuck. 2011. Food crises, food regimes and food movements: Rumblings of reform or tides of transformation? Journal of Peasant Studies, 38 (1), 109-144.

Ghosh, J. 2010. The unnatural coupling: food and global finance. Journal of Agrarian Change, 10(1), 72-86. 
GRAIN. 2011. Pension funds: key players in the global farmland grab. Available from: http://www.grain.org/article/entries/4287-pension-funds-key-players-in-the-global-farmland-grab [Accessed 8 July 2013].

Hall, S. 2012. Geographies of money and finance III: financial circuits and the 'real economy'. Progress in Human Geography, 37(2), 285-292.

Henriques, D. B. 2008. Food is gold, and investors pour billions into farming. New York Times, 5 June. Available from: http://www.nytimes.com/2008/06/05/business/05farm.html?_r=1\&dlbk [Accessed May 2012].

Daviron, B., N. N. Dembele, S. Murphy and S. Rashid. 2011. Price volatility and food security. A report by the High Level Panel of Experts on Food Security and Nutrition of the Committee on World Food Security. Available from:

http://www.fao.org/fileadmin/user_upload/hlpe/hlpe_documents/HLPE-price-volatility-andfood-security-report-July-2011.pdf [Accessed 22 August 2012].

Herman, M., R. Kelly and R. Nash. 2011. Not a game: speculation vs. food security. Oxfam Issue Briefing. October. Available from: http://www.oxfam.org/en/grow/policy/not-gamespeculation-vs-food-security [Accessed 8 July 2013].

IATP. (2008). Commodities market speculation: the risk to food security and agriculture. Minneapolis: Institute for Agriculture and Trade Policy. Available from: http://www.iatp.org/files/451_2_104414.pdf [Accessed 8 July 2013].

IFPRI. 2011. 2011 Global Hunger Index: The challenge of hunger: taming price spikes and excessive food price volatility. Washington, D.C.: International Food Policy Research Institute. Available from: http://www.ifpri.org/sites/default/files/publications/ghi11.pdf [Accessed 8 July 2013]

Irwin, S. H., D. R. Sanders and R. P. Merrin. 2009. Devil or angel? The role of speculation in the recent commodity price boom (and bust). Journal of Agricultural and Applied Economics, 41(2), 377-391.

Irwin, S. H. and D. R. Sanders. 2010. The impact of index and swap funds on commodity futures markets: preliminary results. OECD Food, Agriculture and Fisheries Papers, No. 27, OECD Publishing. Available from: http://dx.doi.org/10.1787/5kmd40wl1t5f-en [Accessed 8 July 2013].

Jones, T. 2010. The great hunger lottery: How banking speculation

causes food crises. World Development Movement. July. Available from: http://www.wdm.org.uk/sites/default/files/hunger\%20lottery\%20report_6.10.pdf [Accessed 8 July 2013].

Kneen, B. 2002. The Invisible Giant. London: Pluto Press.

Kneen, B. 1995. From land to mouth: understanding the food system. Toronto: NC Press. 
Lagi, M., Y. Bar-Yam, K. Z. Bertrand and Y. Bar-Yam. 2011. The food crises: A quantitative model of food prices including speculators and ethanol conversion. Cambridge, MA: New England Complex Systems Institute. Available from: http://necsi.edu/research/social/food_prices.pdf [Accessed 8 July 2013].

Masters, M. 2008. Testimony before US Senate Committee on Homeland Security and Governmental Affairs. Washington, D.C. May 20.

McMichael, P. 2005. Global development and the corporate food regime. In: F.H. Buttel and P. McMichael, eds. New directions in the sociology of global development. Oxford: Elsevier Press.

McMichael, P. 2009. A food regime geneology. The Journal of Peasant Studies, 36 (1), 139-169.

McMichael, Philip 2010. Agrofuels in the food regime. The Journal of Peasant Studies, 37 (4), 609-629.

McMichael, P. 2013. Value-chain agriculture and debt relations: contradictory outcomes, Third World Quarterly, 34 (4), 671-690.

McMichael, P. 2012. The land grab and corporate food regime restructuring. The Journal of Peasant Studies, 29 (3-4), 681-701.

Meyer, G. 2011. Commodity traders hit back at planned US futures curbs. Financial Times, 14 June 2011.

Mittal, A. 2009. The blame game: understanding structural causes of the food crisis”, in J. Clapp and M. Cohen (eds) The global food crisis: governance challenges and opportunities. Ontario: WLU Press, pp.13-28.

Montgomerie, J. 2008. Bridging the critical divide: global finance, financialisation and contemporary capitalism. Contemporary Politics 14(3), 233-252.

Morgan, D. 1979. Merchants of Grain: The Power and Profits of the Five Giant Companies at the Center of the World's Food Supply. New York: Viking.

Murphy, S., D. Burch and J. Clapp. 2012. Cereal Secrets: The World's Largest Grain Traders and Global Agriculture. Oxfam International. Available from:

http://www.oxfam.org/en/grow/policy/cereal-secrets-worlds-largest-grain-traders-globalagriculture [Accessed July 8 2013].

Oxfam France. 2013. Réform bancaire: ces banques françaises qui spéculent sur la faim. Available from:

http://www.oxfamfrance.org/IMG/pdf/rapport_oxfam_france_reforme_bancaire_120213.pdf [Accessed 8 July 2013].

Oxfam International. 2013. Key Eurozone banks step back from food speculation. Press release. Available from: http://www.oxfam.org/en/pressroom/pressrelease/2013-02-18/key-eurozonebanks-step-back-food-speculation [Accessed 8 July 2013]. 
Princen, T. 2001. Consumption and its externalities: where economy meets ecology. Global Environmental Politics, 1(3), 11-30.

Princen, T. 2002. Distancing: consumption and the severing of feedback, in T. Princen, M. Maniates and K. Conca, eds. 2002. Confronting Consumption. Cambridge, MA: MIT Press.

Princen, T. 1997. The shading and distancing of commerce: when internalization is not enough. Ecological Economics, 20(3), 235-253.

Protess 2011: http://dealbook.nytimes.com/2011/12/02/wall-street-groups-sue-regulator-overdodd-frank/

Protess, B. 2012. Wall St. groups sue regulator to challenge new trading rule. New York Times, 2 Dec. Available from: http://dealbook.nytimes.com/2012/09/28/judge-strikes-down-dodd-franktrading-rule/ [Accessed 8 July 2013].

Rosset, P. 2011. Preventing hunger: change economic policy. Nature, 479, 472-473.

Russi, L. 2013. Hungry Capital: The Financialization of Food. Winchester, UK: Zero Books.

Sanders, D.R. and S. Irwin. 2010. A speculative bubble in commodity futures prices? Crosssectional evidence. Agricultural Economics, 41(1), 25-32.

Schoenberg, T. 2012. CFTC to appeal ruling rejecting Dodd-Frank trading limits. Bloomberg News. Bloomberg Businessweek, 15 Nov. Available from:

http://www.businessweek.com/news/2012-11-15/cftc-to-appeal-ruling-rejecting-dodd-franktrading-limits [Accessed 8 July 2013].

Tett, G. 2009. Fool's Gold. New York: The Free Press.

Treanor, J. 2013. Barclays cuts 3,700 jobs in overhaul. The Guardian, 12 Feb. Available from: http://www.guardian.co.uk/business/2013/feb/12/barclays-cuts-3700-jobs-strategicreview?INTCMP=ILCNETTXT3487 [Accessed 8 July 2013].

UNCTAD. 2011. Price formation in financialized commodity markets: the role of information. Available from: http://www.unctad.org/en/docs/gds20111_en.pdf [Accessed 8 July 2013].

US Senate. 2009. Excessive speculation in the wheat market. Majority and Minority Staff Report. Permanent Subcommittee on Investigations, June 24. Washington, DC.

Vander Stichele, M. 2011. Regulating the commodity and exchange derivatives markets: the case of the EU. UNCTAD Public Symposium 2011. 22 - 24 June.

White, B. and A. Dasgupta. 2010. Agrofuels capitalism: a view from political economy. Journal of Peasant Studies. The Journal of Peasant Studies, 37 (4), 593-607.

White, B., S. M. Borras, Jr., R. Hall, I. Scoones, and W. Wolford. 2012. The new enclosures: critical perspectives on corporate land deals. The Journal of Peasant Studies 39(3-4), 619-647. 
World Bank. 2008. Double jeopardy: responding to high food and fuel prices. Paper presented at the G8 Hokkaido-Toyako Summit. 2 July. Available at:

http://siteresources.worldbank.org/INTPOVERTY/Resources/335642-1210859591030/G8-HLsummit-paper.pdf [Accessed 8 July 2013].

World Bank. 2010. Rising Global Interest in Farmland: Can It Yield Sustainable and Equitable Benefits? Washington: D.C.: The World Bank.

World Development Movement. 2011. Stop gambling on food \& hunger: call for immediate action on financial speculation on food commodities. Available from:

http://www.wdm.org.uk/sites/default/files/Food\%20spec\%20statement\%2002.2011_0.pdf [Accessed 8 July 2013].

World Resources Institute. 2008. Rattling supply chains: the effect of environmental trends on input costs for the fast-moving consumer goods industry. Available from:

http://pdf.wri.org/rattling_supply_chains.pdf [Accessed 8 July 2013].

Worthy, M. 2011. Broken markets: how financial market regulation can help prevent another global food crisis. World Development Movement. 